\title{
Kamu Zararı: Türk Kamu Yükseköğretim Kurumları Üzerine Bir Değerlendirme
}

Mustafa Umur TOSUN, Department of Public Finance, Faculty of Economics and Administrative Sciences, Hacettepe University, Turkey; e-mail: utosun@hacettepe.edu.tr

\section{Public Loss: An Evaluation on Turkish Public Higher Education Institutions}

\begin{abstract}
Article 71 in Public Financial Management and Control Law No. 5018 stated public loss as is preventing an increase or causing a decrease in the public resource as a result of a decision, transaction or action that violates the legislation and that stems from their intention, fault or negligence. In this study our aim is to examine the concept of public loss from the point of view of public higher education transactions. For this purpose, we classified one hundred Court of Accounts decisions on the concept of public loss according to their subject, responsibility and expenditure unit. As a result, it is found that ex-post control over the expenditure units does not cover the risky areas for Turkish Higher Education Institutions. Hence ex-post control over expenditure unit do not help Turkish Higher Education Institutions for effciency gains.
\end{abstract}

Keywords : Public Loss, Higher Education, External Control.

JEL Classification Codes : $\quad$ H61, H75, H83.

\section{Öz}

Kamu Mali Yönetim ve Kontrol Kanunu'nun 71.maddesi kamu zararını; kamu görevlilerinin kasit, kusur veya ihmallerinden kaynaklanan mevzuata aykırı karar, işlem veya eylemleri sonucunda kamu kaynağında artışa engel veya eksilmeye neden olmak olarak tanımlanmaktadır. Bu çalışmanın amacı kamu yükseköğretim kurumları açısından kamu zararını incelemektir. Söz konusu amaçla, yüz adet Sayıştay ilamı kamu zararının konusu, sorumlular ve harcama birimi tarafından sınıflandırılmıştır. Sonuç olarak harcama birimleri üzerindeki dış denetimin Türk Yükseköğretim Kurumlarının riskli alanlarını kapsamadığı tespit edilmiştir. Böylelikle harcama birimleri üzerindeki dış denetimin etkinlik kazançları açısından Türk Yükseköğretim Kurumlarına yardımcı olmamaktadır.

Anahtar Sözcükler : Kamu Zararı, Yükseköğretim, Dış Denetim. 


\section{Giriş}

Kamu zararı kavramı, 5018 sayılı Kanun'un 71.maddesinde, "kamu görevlilerinin kasıt, kusur veya ihmallerinden kaynaklanan mevzuata aykırı karar, işlem veya eylemleri sonucunda kamu kaynağında artışa engel veya eksilmeye neden olmak" olarak tanımlanmaktadır. 23.10.2003 tarihinde Başbakanlık tarafından Türkiye Büyük Millet Meclisi'ne gönderilen 71. madde gerekçesinde, maddede kamu zararının tanımlandığı, kamu zararının belirlenmesinde esas alınacak kriterlerin belirlendiği ve kamu zararının oluşması halinde ne tür işlemlerin yapılacağı konusunun da hükme bağlandığı ifade edilmektedir. Bu noktadan hareketle kamu zararı tanımındaki birkaç unsurun eksik olabileceği ifade edilmelidir. Madde metninde, kamu zararının sadece kamu görevlilerinin kusurlu davranışları nedeniyle ortaya çıkabileceği ifade edilmektedir. Başka bir deyişle kusurun bulunmaması kamu zararının da oluşmaması gibi bir anlama gelecek şekilde kullanılması söz konusudur (Özçelik, 2012: 10). Bununla birlikte kamu zararı kamu görevlisinin dışında üçüncü kişilerin davranışlarından da kaynaklanabilir. Bütün söz konusu eksiklerine rağmen kamu zararı, kamu görevlilerinin mevzuata aykırı karar, işlem veya eylemleri sonucunda kamu kaynağında artışa engel veya eksilmeye neden olunmasıdır şeklinde tanımlanabilmektedir (Özçelik, 2012: 11).

Çalışmada, kamu zararına ilişkin Sayıştay tarafından Yükseköğretim Kurumları için kesin hükme bağlanmış kararların "kamu zararı" unsurları açısından bir değerlendirmesi yapılmaya çalışılacak, böylelikle Yükseköğretim Kurumları için bir nev’i kamu zararı envanteri ile riskli alanlar ortaya çıkarılmaya çalışılacaktır.

\section{Kamu Zararının Unsurları ve Kavramlar}

Özçelik (2012: 11-14) ve Bülbül, Akpınar ve Bekar (2015: 46-47), kamu zararının tanımından ve genel haksız fiil sorumluluğunun şartlarından hareketle sorumluluğun dört şartını şu şekilde sıralamaktadır;

- Kamu Görevlisinin varlığı,

- Kamu görevlisinin hukuka aykırı bir karar, işlem veya eyleminin söz konusu olmas1,

- Kamu görevlisinin karar, işlem veya eylemi sonucunda bir zarar meydana gelmiş olmas1,

- Kamu görevlisinin kusurlu olması,

- Kamu görevlisinin fiili ile kamu zararı arasında uygun illiyet bağının buluması.

Herbir unsurda yer alan kavramların açıklanması gerektiği düşünülmektedir. $\mathrm{Bu}$ noktadan harketle birinci unsurdan başlamak üzere kavramlar ele alınacaktır. Kamu görevlisi, Türk Ceza Kanunu (TCK)'nun Tanımlar başlıklı 6.maddesinde, "kamusal faaliyetin yürütülmesine atama veya seçilme yoluyla ya da herhangi bir surette sürekli, süreli veya geçici olarak katılan kişi olarak tanımlanmaktadır". Gözler (2009: 624) ise kamu görevlisinin literatürde, kamu tüzel kişilerinde görev yapan ve kamu hukuku rejimine tabi 
olan bütün kişileri kapsadığını ifade etmektedir. Bu noktadan hareketle, kamu görevlisi 657 sayılı Kanun'dan daha geniş bir geniş bir kesimi kapsamaktadır ${ }^{1}$. İkinci unsurda yer alan diğer bir kavram "hukuka aykırılık" kavramıdır. Hukuka aykırılık, hukuk düzeni tarafından hoşgörülmeyen fiillerdir. "Hukuka aykırılık", işlenen ve kanundaki tarife uygun bulunan fiilin hukuk düzeni ile çelişmesi veya çatışma halinde bulunmasıdır. Yine birinci unsurda yer alan ve diğer kavramlara göre daha açık ifade edilen diğer bir kavram ise "işlem veya eylem" kavramlarıdır. 5018 sayılı Kanun'un 71. maddesi kamu zararına neden olan işlem veya eylemleri saymaktadır. Bunlar sırasıyla;

- İş, mal veya hizmet karşılı̆̆ı olarak belirlenen tutardan fazla ödemede bulunulmasi,

- Mal alınmadan, iş veya hizmet yaptırılmadan ödeme yapılması,

- Transfer niteliğindeki giderlerde, fazla veya yersiz ödemede bulunulması,

- İş, mal veya hizmetin rayiç bedelinden daha yüksek fiyatta alınması veya yaptır1lması,

- İdare gelirlerinin tarh, tahakkuk veya tahsil işlemlerinin mevzuata uygun bir şekilde yapılmaması,

- Mevzuatında öngörülmediği halde ödeme yapılması.

5018 sayılı Kanun'un yukarıda kamu zararına yol açan işlem veya eylemlerine ek olarak, Kamu Zararlarının Tahsiline İlişkin Usul ve Esaslar Hakkında Yönetmelik aşağıda yer alan işlem veya eylemleri de kamu zararına yol açan işlem veya eylemler arasında saymaktadir;

- Kamu idarelerine ait malların kiraya verilmesi, tahsisi, yönetimi, kullanımı ve elden çıkarılması işlemlerinin mevzuata uygun bir biçimde yapılamaması,

- Görevlilere teslim edilen taşınırların zarara uğraması,

- Kamu idaresinin yükümlülüklerinin mevzuatına uygun bir şekilde yerine getirilmemesi nedeniyle kamu idaresine faiz, tazminat, gecikme zammı, para cezası gibi ek mali külfet getirilmesi.

Sorumluların kamu zararına neden olabilmelerinin ikinci unsurunda, yukarıda sayılan işlem veya eylemlerin sonucunda kamu kaynağında artışa engel veya eksilmeye neden olunması yer almaktadır. Kamu kaynağında artışa engel tahakkuk ettirilmesi gereken bir kamu gelirinin tahakkuk ettirilmemiş olması örnek olarak verilebilirken (Özçelik, 2010: 12), eksilmeye neden olunmasına yetkili kılınmamış bir mercinin kamu adına örneğin öğrenci katkı paylarını tahsil ediyor olması verilebilmektedir. Ya da kamu kaynağında eksilmeye, kanunen yapılması yasak bir harcamanın örneğin yıllara yaygın yüklenme 
süresinin üzerinde yüklenmeye girişilmesi örnek olarak verilebilmektedir. Bu noktada kamu kaynağında eksilme örneği olarak literatürde zaman zaman "fazla ve yersiz ödeme" yapılması konusuna ayrı bir yer verilmesi gerektiği düşünülmektedir. Danıştay İkinci Daire'sinin 26 Şubat 2011 tarih E: 2010/6876 K: 2010/5111 sayılı kararında; kişilerden alacaklara ilişkin olarak yapılan fazla ve yersiz ödemelerin kamu zararı olarak nitelendirilemeyeceği belirtilmiştir. Aynı kararda yer alan Danıştay İçtihadı Birleştirme Kurulu'nun 22.12.1973 gün, E: 1968/8, K: 1973/14 sayılı kararının da uygulanması gerektiği ifade edilmelidir. Buna göre kişilere yapılan fazla ve yersiz ödemelerin ancak dava açma süresi içindeki bölümünün geri alım konusu yapılacağı belirtilmektedir.

Kamu zararının unsurlarından üçüncüsü kamu görevlilerinin kusurunun bulunması gerekliliğidir. Sarıyar (2008: 3), kusuru, sorumluluğun kurucu unsuru olarak tanımladıktan sonra tanımının doktrin ve uygulamaya bırakıldığını belirtmektedir. Doktrin ve uygulamadaki hakim görüşe göre, hukuk düzeninin kınadığı, kısaca hoşgörmediği davranış biçimine kusur denilmektedir. Kınamanın nedeni, başka türlü davranma olanağı varken ve zorunlu iken, bu şekilde davranılmayarak, bu tarzdan sapılmış olmasıdır. Türk Ceza Yasası'nın 20-34. maddelerine göre bir kişinin kusurlu sayılıp cezalandırılabilmesi için, ceza yasasına uygun bir eylem (ve netice), bu eyleme (ve neticeye) yönelik irade, eylemin hukuka aykırı olması (eylemi hukuka uygun kılan başka bir hukuk normunun bulunmaması) ve yasa koyucunun bu eylemin cezalandırılmasını engelleyen ve Kanun'da sayılan akıl hastalığı, yaş küçüklüğü, cebir, tehdit gibi nedenlerin bulunmaması gerekir. Cezalandırmayı etkileyen her hal, kusurun bir kriterini oluşturur. Bu nedenle, kusur veya kusurluluk, suçun klasik unsurlarını da içine alan; ancak ondan daha geniş bir kavramdır. Kusur yoksa sorumluluk da bulunmamaktadır (Sarıar, 2008: 3). Kusurun iki türü bulunmaktadır: Kasıt ve ihmal (taksir). Kasıt, hukuka aykırı hususun bilerek işlenmesidir. Başka bir deyişle, kast, haksız fiil failinin zararlı sonucu bilerek ve isteyerek hareket etmesini ifade eder (Kılıçoğlu, 2001:185). Kastta, kişi, fiilinin sonucunu bilmekte ve bunu istemektedir. Örneğin öğrenci katkı payını idare dışında bir hesaba yatırılmasını isteyen üst yönetici gibi. Zarar kasden verilmişse; zarar veren, zararın tamamından sorumludur.

İhmal ise işine, gereken ilgiyi, gereken şekil ve zamanda göstermeme, önem vermeme, vazifeyi düzenli ve zamanında yapmama şeklinde tanımlanmaktadır. Zarara yol açan sonucu bilme veya isteme unsurları yoktur. Kişinin kusurulu sayılmasının sebebi, bu sonucun doğmaması için dikkatsiz, tedbirsiz, özensiz davranması, mesleğinin gerektirdiği özeni ortaya koymamasıdır. İhmalin değişik dereceleri bulunmaktadır. Ağır ihmal ${ }^{2}$ ve hafif ihmal $^{3}$ ihmalin dereceleridir (Kılıçoğlu, 2001: 185-186).

2 Ağır ihmal, bir kimsenin aynı olayda göstermesi gereken en basit dikkat ve özenin gösterilmemesidir. Örneğin idarede yolsuz ve usulsüz işlemlere göz yuman üst yöneticinin davranışl gibi.

3 Çok dikkatli ve özenli kişilerin aynı olayda gösterdiği dikkat ve özenin gösterilmemesi söz konusudur. Örneğin harcama yetkilisinin gerçekleştirdiği ihalelerden birinde geçici teminat geç yatırlldı̆̆ halde ihaleye devam etmesi gibi. 
Son unsur olarak kamu görevlilerin, eylemleri ile kamu zararı arasında uygun illiyet bağının bulunması gerekmektedir. İlliyet bağı ya da nedensellik bağı, hukuki sonuç ile sonucu ortaya çıkaran olgular arasındaki bağı belirten bir kavramdır. Ortaya çıkan zarar ile fiil arasındaki bağlantı olarak tanımlanabilir. Örneğin özel bütçe kapsamındaki Yükseköğretim Kurumlarında tahsil edilmesi gereken öğrenci katkı paylarının, Yükseköğretim Kurumu bünyesindeki Teknoloji Geliştirme Bölgelerinde kurulmuş bir şirketin hesabına yatırılmasına onay, talimat verilmesi kamu kaynağında artışa engel olunmak suretiyle kamu zararına yol açmaktır. Söz konusu durumda kamu zararına neden olan iş veya eylem öğrenci katkı paylarının Teknoloji Geliştirme bünyesinde yer alan şirkete yatırılması talimatıdır. Her ne kadar 5018 sayılı Kanun'un 72. maddesine göre yetkisiz tahsil talimatı verilmiş ise de, örnekteki durum bakımından konunun kamu kaynağında eksilmeye neden olma bakımından da cezalandırılması gerektiği düşünülmektedir. Kamu zararının tespiti açısından yukarıda sıralanan herbir unsurun kontrol, denetim, inceleme, kesin hükme bağlama veya yargılama sonucunda tespitinde önem arz eden hususlardır.

\section{Kamu Zararının Tespiti}

5018 sayılı Kanun'un 71. maddesinin son iki fikrası kamu zararının tespiti ve tahsiline ilişkin esasları düzenlemektedir. Buna göre Maliye Bakanlığı'nın teklifi ve Bakanlar Kurulu tarafindan 19.10.2006 tarih ve 26324 sayılı Resmi Gazetede "Kamu Zararlarının Tahsiline İlişkin Usul ve Esaslar Hakkında Yönetmelik” yayımlanmıştır. İlgili Yönetmeliğin 6.maddesine göre; "kontrol, denetim veya inceleme, Sayıştayca kesin hükme bağlama, Adlî, İdarî veya askerî yargılama sonucunda tespit edilir” hükmü yer almaktadır. Sıralı olarak hükümde yer alan tespit türlerinin 5018 sayılı Kanun ile getirilen iç ve dış denetimi kapsadığ1 düşünülmektedir. Buna göre kontrol sürecinden "ön malî kontrol”, denetim veya incelemeden "İç Denetim veya Sayıştayca" yapılacak denetimin anlaşılması gerektiği düşünülmektedir. Sayıştay tarafından yapılan dış denetim bir tarafa bırakılacak olursa kamu zararının tespitinde "Ön Malî Kontrol" (ex-ante financial control) ve "İç Denetim"'den (internal audit) oluşan "İç Kontrol” müessesesinin önemli rol oynadığ belirtilmelidir. Avrupa Komisyonu iç kontrolü “idarenin belirlenmiş amaç ve politikalarına uygun olarak faaliyetlerin etkin, ekonomik ve verimli bir şekilde yürütülmesini, varlık ve kaynakların korunmasını, muhasebe kayıtlarının doğru ve tam olarak tutulmasını, mali bilgi ve yönetim bilgisinin zamanında ve güvenilir olarak üretilmesini sağlamak üzere idare tarafindan oluşturulan organizasyon, yöntem, süreç ile iç denetimi kapsayan mali ve diğer kontroller bütünüdür" şeklinde tanımlamaktadır (European Comission, 2006: 3). Nitekim 5018 sayılı Kanun'un 55. maddesi de Avrupa Komisyonunun iç kontrol tanımını aynen iç mevzuata aktarmıştır. Avrupa Komisyonunun ve 5018 sayılı Kanun'un 55.maddesindeki tanımından da anlaşılabileceği gibi, iç kontrol sistemi malî ve malî olmayan bütün süreçleri bünyesinde barındırmaktadır. İdare içinde yer alan herbir çalışan da, iç kontrol sisteminin bir parçasını oluşturmaktadır. Bu noktadan hareketle idarede çalışanların bütününün kamu zararının tespit edilmesinde rollerinin bulunduğunun da ifade edilmesi gerekir. Bu noktadan hareketle mevzuatta yerini bulan inceleme olgusundan ön malî kontrolü yapmakla görevli olanlar, iç denetçiler ve idare çalışanların tümünün "kamu zararı"nın tespit edilmesinde sorumlulukları olduğunu söylemek yanlış bir tespit olmayacaktır. İdare çalışanları rollerinin olduğu tespitine rağmen, kamu zararının tespitinde en önemli denetim şekli “dış denetim” 
Tosun, U. (2016), "Kamu Zararı: Türk Kamu Yükseköğretim Kurumları

Üzerine Bir Değerlendirme”, Sosyoekonomi, Vol. 24(30), 155-168.

mekanizmasıdır. Zira kamu zararının hükme bağlanması Sayıștay tarafından yerine getirilmektedir.

6085 sayılı Sayıştay Kanunu'nun Tanımlar başlıklı 2. maddesi kamu zararını, 5018 sayılı Kanuna atfen tanımlamaktadır. Aynı maddede, "yargılamaya esas rapor; Sayıştay dairelerince yapılacak yargılamaya esas olmak üzere, denetçiler tarafından genel yönetim kapsamındaki kamu idarelerinin hesap ve işlemlerinin denetimi sırasında tespit edilen kamu zararına ilişkin düzenlenen rapor" olarak tanımlanmaktadır. 6085 sayılı Kanun'un 5. maddesi kapsamında, kamu zararının hükme bağlanması görevi Sayıştay’a verilmiş bulunmaktadır. Kanun, sorumluların kamu zararından tek başlarına veya birlikte tazmine yükümlü olduklarını da hüküm altına almıştır. Sayıştay daireleri söz konusu kamu zararını, hesap mahkemesi sıfatıyla hükme bağlamakla görevlendirilmiş bulunmaktadır. Genel yönetim kapsamındaki kamu idarelerinin hesap ve işlemlerinin denetimi sırasında denetçiler tarafından kamu zararına yol açan bir husus tespit edildiğinde sorumluların savunmaları alınarak mali yılsonu itibariyle yargılamaya esas rapor düzenlenir. Yargılamaya esas raporun düzenlenmesinde, tebliğ tarihinden itibaren otuz gün içinde cevap vermeyen sorumluların savunmaları dikkate alınmamaktadır. Yargılamaya esas raporlar eki belgelerle birlikte Sayıştay Başkanlığa sunulur. Sayıştay Başkanlığı, bu raporları en geç onbeş gün içinde hesap yargılamasının yapılacağı daireye gönderir. Yargılamaya esas raporda belirtilen hususlar için Sayıştay Başsavcılı̆̆ı'nın yazılı görüşleri alınır. Daire başkanı, başsavcılığın yazılı düşüncesini içeren yargılamaya esas raporu düşüncesini bildirmesi için üyelerden birine verir. Üye kendisine verilen yargılamaya esas rapor üzerinde gerekli incelemeyi yapar ve yazılı düşüncesi ile birlikte daire başkanlığına geri verir ve raporda konu edilen hesap ve işlemlerin yargılanmasına başlanır. Hesap yargılaması sırasında savcı da hazır bulunur ve görüşünü açıklar. Hesap yargılaması sonucunda, işlemlerin uygunluğuna veya tazminine hükm olunur. Bu hükümler dışında, gerekli görülen hususların ilgili mercilere bildirilmesine karar verilebilir. Sayıştay Denetiminin yürütülmesinde ve kamu zararının tespitinde, kamu idarelerinin gelir, gider ve malları ile bunlara ilişkin mali nitelikteki tüm hesap ve işlemlerinin kanunlara ve diğer hukuki düzenlemelere uygun olup olmadığının tespitini kapsayacak şekilde yapılması öngörülmektedir.

Sayıştay denetimleri sırasında 6085 sayılı Kanun'un 6. maddesi kapsamında geniş yetkilerle donatılmış durumdadır. Sayıştay, kendisine verilen görevlerle ilgili olarak kamu idareleri ve görevlileriyle doğrudan yazışmaya, gerekli gördüğü belge, defter ve kayıtları göndereceği mensupları aracılığıyla görmeye, mallar hariç dilediği yere getirtmeye, sözlü bilgi almak üzere her derece ve sınıftan ilgili memurları çağırmaya, kamu idarelerinden temsilci istemeye yetkili kılınmıştır. Sayıştay, denetimine giren işlemlerle ilgili her türlü bilgi ve belgeyi, kamu idareleri ile bankalar dâhil diğer gerçek ve tüzel kişilerden isteyebilmektedir. Sayıştay, denetimine giren kamu idarelerinin işlemleriyle ilgili kayıtları, eşya ve malları, işleri, faaliyetleri ve hizmetleri görevlendireceği mensupları veya bilirkişiler tarafından yerinde ve işlem ve olayın her safhasında incelemeye yetkilidir. Sayıştay, kamu idarelerinin hesap, işlem ve faaliyetleri ile mallarını, hesap veya faaliyet dönemine bağlı olmaksızın yılı içinde veya yıllar itibariyle denetleyebileceği gibi sektör, program, proje ve konu bazında da denetleyebilmektedir. Denetimler sırasında gerekli görülmesi halinde, Sayıştay dişından uzman görevlendirilebilmekte, söz konusu bilirkişi ve uzman 
görevlendirilmesine ilişkin esas ve usuller ayrı bir yönetmelikle belirlenmektedir. $\mathrm{Bu}$ noktadan hareketle Yükseköğretim Kurumları açısından "kamu zararına" sebebiyet verilen alanların tespit edilmesi ve varsa başkaca risk alanlarına işaret edilmesi Sayıştay tarafından hüküm altına alınan kamu zararlarının incelenmesi ile mümkün olabilecektir.

\section{Mali Açıdan Kamu Yükseköğretim Kurumları}

Kamu Yükseköğretim Kurumları açısından yapılacak bir değerlendirmede mali kaynakların belirlenmesi ve kamu zararına ilişkin ilamların söz konusu kaynaklar üzerinden yapılmasının önemli olacağı değerlendirilmektedir. 5018 sayılı Kanun’a göre, kendisine ödenek tahsis edilen herbir birimin harcama birimi olarak belirlendiği bilinmektedir. Kaynakların kullanımı açısından harcama birimleri önemli olmakla birlikte, yükseköğretim kurumların mali kaynaklarının birkaç şekilde temin edildiği bilinmektedir.

Kamu yükseköğretim kurumlarının mali, kaynaklarının temelde iki kaynaktan sağlandığını söylemek mümkündür. Bunlardan birincisi hazine yardımı, ikincisi ise öz gelirdir. Hazine yardımı, Yükseköğretim Kurumlarının yılı için öngörülen bütçelerinden 2547 sayılı Yükseköğretim Kanun'unda sayılı öz gelirlerinden çıkarılmasılyla devletçe karşılanılan kısmı olarak tanımlanabilmektedir. Öz gelirler ise 2547 sayılı Kanun'un 55. maddesinde sayılan gelir kaynaklarından elde ettikleri gelirlerdir. Söz konusu öz gelir Yükseköğretim Kurumlarının bütçelerinde, gelirli ödenek kaydedilmek suretiyle bütçeleştirilmektedir. Bu noktadan hareketle 2547 sayılı Kanun'un 55. maddesinin a) fikrası dışında kalan; kurumlarca yapılacak yardımlar, alınacak harç ve ücretler, yayın ve satış gelirleri, taşınır ve taşınmaz mal gelirleri, döner sermaye işletmelerinden elde edilecek gelirler ile bağış, vasiyet ve diğer gelirler öz gelir kapsamında değerlendirilmektedir. Yükseköğretim kurumları açısından; alınacak harç ve ücretler, yayın ve satış gelirleri, taşınır ve taşınmaz mal gelirleri ile bağış, vasiyet ve diğer gelirler (B) işaretli cetvelde öz gelir, her yıl bütçeye konulacak ödenekler ile kurumlarca yapılacak yardımlar yine (B) işaretli cetvelde hazine yardımı olarak ödenekleştirilmektedir. Döner sermaye gelirleri yükseköğretim kurumları bütçeleri ile ilişkilendirilmemektedir ${ }^{4}$. Döner sermaye gelirlerinin bütçeyle ilişkilendirilmemesinin sebebi; genel yönetim kapsamındaki kamu idarelerine kanunla verilen asli ve sürekli kamu görevlerine bağlı olarak ortaya çıkan ve genel idare esaslarına göre yürütülmesi mümkün olmayan mal ve hizmet üretimine ilişkin faaliyetlerin sürdürülmesi için, kamu idaresine bağlı olarak tahsis edilen sermaye üzerinden elde edilen gelirler olmasıdır. Başka bir deyişle asli ve sürekli kamu görevi fonksiyonu eğitim olan yükseköğretim kurumlarının örneğin hekim yetiştirmek için kurulan eğitim-araştırma hastanesindeki atıl kapasitenin kullanılması için sağlanan sermaye ve söz konusu sermaye üzerinden elde edilen gelirleri ifade etmektedir. Yukarıda ifade edilen Yükseköğretim Kurumları gelirlerinden oluşan ödenekler özellikle hazine yardımı, toplu ödenek şeklinde üst yöneticilere (rektör) tahsis edilmektedir. Toplu şekilde yükseköğretim kurumlarına tahsis 
edilen ödenekler üst yönetici tarafından harcama birimlerine dağıtılmaktadır. 5018 saylı Kanun'un harcama birimini; "kamu idaresi bütçesinden ödenek tahsis edilen ve harcama yetkisi bulunan birim" olarak tanımlamaktadır. Söz konusu Kanun'un 31. maddesi ise harcama yetkilisini tanımlamaktadır. Buna göre harcama yetkilisi, "bütçeyle ödenek tahsis edilen her bir harcama biriminin en üst yöneticisi harcama yetkilisi” olarak tespit edilmiş bulunmaktadır. Dolayısıyla kamu yükseköğretim kurumları yukarıda ifade edilen ödenekleri toplu halde aldıktan sonra aşağıda sunulan harcama birimleri ve yetkilileri aracılığıyla harcama yetkilerini kullanmaktadırlar. Hemen ifade edilmelidir ki, aşağıdaki tabloda yer alan harcama birimleri ve yetkilileri dişındakilerin harcama yetkileri bulunmamaktadır. Yüksekögretim kurumu adına aşağıdaki tabloda yer alanların dışındaki yetkililerin harcama yetkileri bulunmamaktadır.

Kamu zararı açısından harcama birimleri ve yetkililerinin tespiti önemli görülmektedir. Zira kamu zararının kusurlu işlem veya eylemlerine bağlanmış olması bunların kimler ya da hangi birimler eliyle gerçekleştirebileceğini açısından önem arz etmektedir.

Maliye Bakanlığı tarafindan özel bütçeli idarelerde harcama yetkililerinin kimler olduğu "Harcama Yetkilileri Genel Tebliğ (Seri No. 1)" ile belirlenmiştir. Genel Tebliğ'de yer alan "harcama yetkilileri"' nin üniversiteler için kısıtlanmış biçimi aşağıdaki Tablo-1'de sunulmaktadir.

Tablo: 1

Yükseköğretim Kurumlarında Harcama Yetkilileri

\begin{tabular}{|c|c|c|c|}
\hline Teşkilat Yapısı & Üst Yönetici & $\begin{array}{l}\text { Bütçeyle Ödenek Tahsis Edilen } \\
\text { Harcama Birimi }\end{array}$ & $\begin{array}{l}\text { Harcama } \\
\text { Yetkilisi }\end{array}$ \\
\hline $\begin{array}{l}\text { Üniversite ve Yüksek } \\
\text { Teknoloji Enstitüleri }\end{array}$ & Rektör & $\begin{array}{l}\text { Genel Sekreterlik } \\
\text { Daire Başkanlığı } \\
\text { Hukuk Müşavirliği } \\
\text { Fakülte } \\
\text { Yüksekokul } \\
\text { Meslek Yüksekokulu } \\
\text { Enstitü } \\
\text { Hastane } \\
\text { Merkez } \\
\text { Bölüm } \\
\text { Savunma Uzmanlığı }\end{array}$ & $\begin{array}{l}\text { Genel Sekreter } \\
\text { Daire Başkanı } \\
\text { Hukuk Müşaviri } \\
\text { Dekan } \\
\text { Müdür } \\
\text { Müdür } \\
\text { Müdür } \\
\text { Başhekim } \\
\text { Müdür } \\
\text { Başkan } \\
\text { Savunma Uzmanı }\end{array}$ \\
\hline Enstitü & $\begin{array}{l}\text { Başkan, Genel } \\
\text { Müdür } \\
\text { veya Müdür }\end{array}$ & $\begin{array}{l}\text { Genel Sekreterlik } \\
\text { Müstakil Daire Başkanlığı } \\
\text { Daire Başkanlığı } \\
\text { Özel Kalem Müdürlüğü } \\
\text { Sivil Savunma Uzmanlığı } \\
\text { Savunma Uzmanlığı } \\
\text { Hukuk Müşavirliği } \\
\text { Müdürlük } \\
\text { Koordinatörlük }\end{array}$ & $\begin{array}{l}\text { Genel Sekreter } \\
\text { Daire Başkanı } \\
\text { Daire Başkanı } \\
\text { Özel Kalem } \\
\text { Müdürü } \\
\text { Sivil Savunma } \\
\text { Uzmanı } \\
\text { Savunma Uzmanı } \\
\text { Hukuk Müşaviri } \\
\text { Müdür } \\
\text { Koordinatör }\end{array}$ \\
\hline
\end{tabular}


Tablo 1'den de görülebileceği gibi, Yükseköğretim Kurumları açısından harcama yetkisini elinde bulunduranlar kamu zararının oluşması açısından potansiyel alanları ifade etmektedir. Fakülteler, Enstitüler, Daire Başkanlıkları (Yapı İşleri ve Teknik, İdari ve Mali İşler, Sağlık, Kültür ve Spor, Öğrenci İşleri, Kütüphane ve Dokümntasyon, Strateji Geliştirme, Personel, Bilgi İşlem Daire Başkanlıkları), Hukuk Müşavirliği, Yüksekokul, Meslek Yüksekokulu, Hastaneler, Araştırma ve Uygulama Merkezleri harcama birimi ve bunların en üst yöneticileri de harcama yetkilisi olarak tespit edilmiş bulunmaktadır. Yükseköğretim Kurumlarında söz konusu birimler ve yetkilileri kamu zararı açısından potansiyel kaynakları oluşturmaktadır.

Kamu zararının tespitinde denetimin rolü daha önce ifade edilmişti. Yine Sayıştay’ın kamu zararını hükme bağlamakla görevlendirildiği de ifade edilmişti. Bu noktadan hareketle kamu yükseköğretim kurumları bağlamında harcama birimleri açısından hangi alanlarda kamu zararının hükme bağlandığı, hangi alanların eksik ya da incelemenin yetersiz kalabildiği hem uygulayıcılar hem de denetim elemanları açısından kayda değer bir soru olarak karşımıza çıkmaktadır. Bu amaçla Sayıştay ilamlarının incelenerek, kamu yükseköğretim kurumlarının harcama birimleri açısından riskli bölgelerin, iç ve dış denetim elemanlarının bundan sonra yapacakları denetimlere yol gösterici olabileceği ifade edilmelidir.

Denetimlerin işlevselliği açısından, iç denetim kurum içinde yetersiz kaldığ söylenebilir. İç denetimin yetersiz kalmasında birkaç faktörün önemli rol oynadığ kanaati taşınmaktadır. Bunlardan ilki iç denetçilerin atanma usulü ve bağlı olduğu makamla ilgilidir. İç denetçi kadrolarındaki denetim elemanları üst yönetciye bağlı olarak çalışmakta denetim talimat ve izinleri üst yöneticiler tarafından belirlenmektedir. Her ne kadar üst yönetici ile iç denetçiler arasındaki çatışmaların çözümü "İç Denetçiler Koordinasyon Kurulu"'na verilmişse de atama yetkisini elinde bulunduranlarla denetim elemanlarının çatışma konumunda olmasını beklemek gerçekçi olmayacaktır. İkinci olarak eski alışganlıkların halen devam ediyor olması da etkin bir denetim ve kamu zararı tespiti işlevini olumsuz etkileyebilmektedir. 5018 sayılı Kanun'un ile getirilen yeni denetim anlayışı klasik teftiş anlayışından farklıdır. İç denetim elemanları kurumların iş ve işlemlerini yürürlükte bulunan mevzuata uygun olarak gerçekleştirdiklerini kontrol etmekle yükümlü bulunmaktadırlar. Bununla birlikte kurumların iş ve işlemlerinde etkinliği, ekonomikliği, verimliliği nasıl artıracaklarına ilişkin yol da gösterici olmaları gerekmektedir. Hâlbuki iç denetçi müessesinin kuruluşundan itibaren mevcut denetim elemanların eski alışkanlıkları sürdüregelmeleri danışmanlık hizmetinin layığıyla yerine getirilmesi önündeki önemli engellerden biri olarak mevcudiyetini sürdürmektedir. Yukarıda ifade edilen engellere yenilerini eklemek mümkündür. Bu noktadan hareketle kamu zararının tespiti açısından en öenmli rol dış denetim müessesinin (Sayıştay) üzerinde kalmaktadır.

\section{5. İlamlarla Kamu Yükseköğretim Kurumlarında Kamu Zararı}

Dış denetimin gerek denetim fonksiyonu gerekse kamu zararının tespiti konusunda görevlendirilmiş olması, Sayıştay daire kararlarını önemli bir konuma getirmektedir. Bu noktadan hareketle "kamu zararı" hakkında Kamu Yükseköğretim Kurumları 2014 hesap 
y1lına ilişkin rastgele seçim yöntemiyle 100 adet karar incelenmiştir. 100 adet ilamın, Sayıştay kamu zararının denetimlerinin tümünü temsil etmesi mümkün olmamakla birlikte, Kamu Yükseköğretim Kurumları riskli alanlarının tespit edilmesi açısından yol gösterici olabileceği düşünülmektedir. Daire kararlarının yer alan kamu zararlarının bir kısmı tahsil edilmiş bir kısmı tazmin edilmiş diğer bir kısmının ise beraatine hükmedilmiştir. Tazmin kararı verilen ilamların temyiz sürecine gitmiş olmasının başka bir deyişle kesinleşmesinin çalışmamız açısından bir önemi bulunmamaktadır. Zira çalışma kamu zararı doğması muhtemel alanların tespitine yönelmiş bulunmaktadır.

Tablo-1'de verilen Kamu Yükseköğretim Harcama birimleri ile söz edilen 100 adet dış denetim daire kararının birleştirilmiş şekli aşağıdaki tabloda sunulmaktadır.

\section{Tablo: 2}

\section{İlamlarla Kamu Zararı Tespit Edilen Alanlar}

\begin{tabular}{|l|l|c|c|}
\hline $\begin{array}{l}\text { Bütçeyle Ödenek Tahsis Edilen } \\
\text { Harcama Birimi }\end{array}$ & $\begin{array}{l}\text { İlamda Sorumlu Tutulan } \\
\text { Yetkililer }\end{array}$ & $\begin{array}{c}\text { İlamın Konusu ve İlgili } \\
\text { Olduğu Birim (Adet) }\end{array}$ & $\begin{array}{c}\text { Yüzde } \\
\text { (\%) }\end{array}$ \\
\hline Genel Sekreterlik & Genel Sekreter /Ger.Gör. & 13 & 13 \\
Daire Başkanlığ1 & Daire Başkanı / Ger. Gör. & 62 & 62 \\
Hukuk Müşavirliği & Hukuk Müşaviri & - & - \\
Fakülte & Dekan / Ger.Gör. & - & - \\
Yüksekokul & Müdür / Ger. Gör. & 2 & 2 \\
Meslek Yüksekokulu & Müdür / Ger. Gör. & 2 & 2 \\
Enstitü & Müdür /Ger.Gör. & - & - \\
Hastane /Döner Sermaye & Başhekim / Başmüdür & 17 & 17 \\
Merkez & Müdür /Ger. Gör. & 4 & 4 \\
\hline & & 100 & 100 \\
\hline
\end{tabular}

Tablo 2'den çıkarılabilecek önemli tespitler bulunmaktadır. Dış denetim birimi tarafından karara bağlanan kamu zararlarının \%62'lik bölümünün, Kamu Yükseköğretim Kurumlarının daire başkanlıklarının sorumluluk alanları içindeki konulardan oluştuğunu belirtmek gerekmektedir. Söz konusu durumun normal olduğu düşünülmektedir. Zira Kamu Yükseköğretim Kurumlarında daire başkanlıkları hazırlayıcı idari işlem tesis etmekte, ilgili birimler ise tamamlayıcı idari işlem yapmaktadırlar. Örneğin bir Fakültede görevli öğretim üyesinin maaş bordrosu Personel Daire Başkanlığı tarafından hazırlanmakta, harcama yetkilisi Fakülte dekanı tarafından imzalanmaktadır. Bu gibi durumlarda, Tablo-2'de yer alan ilamda sorumlu yetkili kaydı harcama yetkilisi Fakülte Dekanı olmakla birlikte Daire Başkanlığına yapılmıştır. Aşağıda yer alan gruplanmış listede her ne kadar çeşitli konularda kamu zararı kararlarının alındığı görülüyor ise de, kararların büyük bölümünün ücret ve ücretin unsuru olan ödemelere ilişkin olduğu tespit edilmiştir.Bunlar içinde personele yapılan fazla, yersiz ve yanlış ücret ödemelerin önemli bir yer tuttuğu; dış denetim incelemeleri açısından ücret ödemelerinin önemli bir konu olarak görüldüğü ifade edilmelidir. Dolayısıyla ücret ödemelerinin ilişkin Kamu Yükeköğretim Kurumlarının önemli bir risk alanına sahip oldukları ifade edilmelidir.

- Geliştirme Ödeneğinin ödenmesinde yapılan yanlışlıklar,

- Kaza sonrası kazayla ilgili olmayan makam aracı bakımının kurum bütçesinden yapilmas1, 
- Muayene ve kabul komisyonu işinin hizmet alımı yoluyla yapılması,

- Yapım işine ait gecikme cezası kesilmemesi,

- Kurum çalışanlarına fazla ödemede bulunulması,

- Eksik gecikme cezası,

- İdari para cezasının kurum bütçesinden ödenmesi,

- Kamu araçları için kasko bedeli ödenmesi,

- Fiyat farkı ödenmesi,

- Emanet hesaptan teknik personel kesintisi, gecikme cezası gibi hesapların bulunmas1,

- Yanlış birim fiyat kullanımı ile fazla ödeme yapılması,

- Eksik KDV tahsilatı yapılması,

- Yanlış birim fiyat uygulaması,

- İkmal inşaatında fiyat farkının hatalı ödenmesi,

- Görevli, izinli, raporlu olunan dönemde ek ders ücreti ödemesi yapılması,

- Yanlış yabancı dil tazminatı hesaplanarak ödenmesi,

- Yanlış yolluk yevmiye ödenmesi,

- Lojmanlara ait doğalgaz abonelik ücreti ödenmesi,

- Yurt ve lojmanların elektrik ve su tüketim miktarlarının bir kısmının ilgililerden tahsil edilmemesi,

- Fiilen teslim alınmayan mobilyaya fatura bedelinin ödenmesi,

- İnşaat kaba temizlik işinin kurum bütçesinden ödenmesi,

- Maaş farklarının eksik ödenmesi nedeniyle faiz giderine neden olunması,

- Hizmet alımı işinde personelin maaşlarının zamanında ödenmemesi,

- Mal alımının piyasa fiyatının üstünde gerçekleştirilmesi,

- Hatalı gösterge ile üniversite ödeneği ödenmesi,

- Engelli sigorta priminin hazine tarafından karşılanmasının fiyat farkı hesabında dikkate alınmamas1,

- Doğalgaz faturalarına ilişkin gecikme bedeli ödenmesi,

- Avans ödemesinde limitlere riayet edilmemesi,

- Damga vergisi tahsil edilmemesi,

- Özel Güvenlik Alımı ihalesinin aylara bölünmesinde eksiklik yapılması kamu zararı olarak ilama bağlanan örnekler olarak dikkkati çekmektedir.

Kamu zararı açısından Kamu Yükseköğretim Kurumlarının ikinci önemli risk alanını, Döner Sermayelerin (DÖSE) faaliyet alanını ilgilendiren Eğitim-Araştırma Hastaneleri oluşturmaktadır. İncelenen ilamlar içinde, dış denetimler sonucunda kamu 
zararına ilişkin \%17'lik bölümün Eğitim-Araştırma Hastanelerinin faaliyet alanında gerçekleştiği tespit edilmiştir.

- Ek Ödeme yanlışlık yapılması,

- Gecikme cezası ödenmesine neden olunması,

- İdari personele performans ek ödemesi yapılması,

- Merkez Müdürüne DÖSE'den ek ödeme yapılması,

- Müstesna olunan elektrik tüketim vergisinin ödenmesi,

- Dekan ve Dekan Yardımcısına mesai içi performans ek ödemesi yapılması,

- Hastane inşaatında fazla ödemede bulunulması,

- Sağlık Uygulama Tebliği'nde yer alan özel oda farkının tahsil edilmemesi,

- Kiralama işinin rayiç bedelin altında yapılması,

- DÖSE tarafından hizmet akdi olmaksızın doktor istihdamı nedeniyle mahkeme kararıyla ücret, kıdem tazminatı ve yargılama gideri ödenmesi,

- Formasyon eğitim gelirlerinin dağıtımı,

- Eksik KDV Ödenmesi,

- Araştırma ve Uygulama Merkezleri ve Sürekli Eğitim Merkezi Müdür ve Yrd. yönetici payı ödenmesi,

- Gelire katkıları bulunmayan dekanlık personeline DÖSE'den ek ödeme yapılması,

- Medikoda görevli başhekim ve yardımcısına ikinci görev ödeneği ödenmesi,

- Yapı İşleri ve Teknik Daire Başkanına ek ödeme yapılması ikinci risk bölgesine verilebilecek örnekler olarak ön plana çıkmaktadır.

Kamu Yükseköğretim Kurumlarında üçüncü risk bölgesini Genel Sekreterlikler oluşturmaktadır. 100 kamu zararı ilamı içinde 13 kamu zararı ilamı Genel Sekreterlik makamlarını ilgilendiren konularda gerçekleşmiştir. Bunlara verilebilecek örnekler ise şöyle siralanabilmektedir;

- Özel kalemde fiilen görev yapmadıkları halde geliştirme ödeneği ödenmesi,

- Geçici görevli olduğu dönemde geliştirme ödeneği ödenmesi,

- Yanlış aile yardımı ödenmesi üçüncü risk bölgesine aittir.

Genel Sekreterlikler bünyesindeki kamu zararları incelendiğinde dış denetim açısından yine ücret ve ücret unsurlarının ön plana çıktığı gözlemlenmektedir. Buna ek olarak, yüksekokul, meslek yüksekokulu ve araştırma-uygulama merkezleri için de ücret ve ücretin unsurlarının ön planda dış denetimin konusunu oluşturduğunu söylemek gerekmektedir. Kamu zararı için konu her ne kadar önemliyse de, sorumluların tespiti açısından da bir takım tespitler Tablo 2'de yer almaktadır.

Tablo 2'de ilamlarda sorumlu tutulan kamu görevlileri gösterilmektedir. Harcama Yetkilileri Genel Tebliğ (Seri No. 1) uygun olarak incelenen ilamların tamamında harcama 
yetkilileri, gerçekleştirme görevlileri sorumlu kişiler olarak savunması alınan kişiler olmuşlardır. Yüz ilam içinde bir ilamda muhasebe yetkilisinin ve yapı işlerine ilişkin ilamlarda teknik personelin de sorumlular arasında yer aldığı görülmektedir. Bu noktada gerçekleştirme görevlisi kavramına açıklık getirilmesi gerektiği düşünülmektedir.

5018 sayılı Kanun'un 33.maddesi 2.fikrasında; “gerçekleştirme görevlileri, harcama talimatı üzerine, işin yaptırılması, mal veya hizmetin alınması, teslim almaya ilişkin işlemlerin yapılması, belgelendirilmesi ve ödeme için gerekli belgelerin hazırlanması görevlerini yürütürler" şeklinde tanımlanmaktadır. Kanun'un yine 33.maddesinin 4.fikrasında, 5018 sayılı Kanun çerçevesinde yapmaları gereken iş ve işlemlerden sorumlu oldukları belirtilmektedir. Bu noktadan hareketle 5018 sayılı Kanun belirli bir kişiyi gerçekleştirme görevlisi olarak işaret etmemiş harcama talimatı üzerine yerine getirilmesi gereken görevleri sıralamıştır. Gerçekleştirme görevlisinin tanımı, Maliye Bakanlığı tarafından yayımlanan İç Kontrol ve Ön Mali Kontrole İlişkin Usul ve Esaslar Yönetmeliğinin 12. maddesinin 3 fikrasında yapılmıştır. Buna göre; "harcama yetkilileri, yardımcıları veya hiyerarşik olarak kendisine en yakın üst kademe yöneticileri arasından bir veya daha fazla sayıda gerçekleştirme görevlisini ödeme emri belgesi düzenlemekle görevlendirir. Ödeme emri belgesini düzenlemekle görevlendirilen gerçekleştirme görevlileri, ödeme emri belgesi ve eki belgeler üzerinde ön malî kontrol yaparlar. Bu gerçekleştirme görevlileri tarafindan yapılan kontrol sonucunda, ödeme emri belgesi üzerine "Kontrol edilmiş ve uygun görülmüştür" şerhi düşülerek imzalanır". Yönetmeliğin ilgili maddesinden de anlaşılabileceği gibi, gerçekleştirme görevlisi belirli bir kişi örneğin Kamu Yükseköğretim Kurumlarında dekan yardımcıları olabileceği gibi harcama yetkilisi tarafından hiyerarşik olarak kendisine en yakın üst kademe yöneticileri arasından birini de söz konusu işi yapmakla görevlendirebilmektedir. Bu durum, incelenen diş denetim ilamlarına da yansımış bulunmaktadır. İlamlarda, zaman zaman proje yürütücülerinin, teknik personel vb. gerçekleştirme görevlisi olarak kamu zararından sorumlu tutuldukları gözlemlenmektedir. Dolayısıyla sorumluluk açısından, ödeme emri belgesi ve eki belgeleri düzeneleyenlerin sorumlu olduklarını ve bu durumun incelenen ilamlarla sabit olduğunu belirtmek gerekmektedir.

\section{Sonuç}

5018 say1lı Kanun'un en önemli düzenlemelerinden bir tanesi "kamu zararı" olgusudur. Çalışmada kamu zararı olgusu, dış denetim birimi ilamları çerçevesinde Kamu Yükseköğretim Kurumları için risk oluşturması muhtemel alanlar bakımından incelenmeye çalışılmıştır. Dış denetimin kamu zararı ilamları incelendiğinde birkaç hususun ön plana çıktığı ancak denetim açısından gözden kaçan hususların da bulunduğu ifade edilmelidir.

Birinci olarak kamu yükseköğretim kurumlarının bazında bazı harcama birimlerinde denetimin yoğunlaştığı, dolayısıyla kamu zararı ilamlarının bu çerçevede sınırlı kaldığ gözlemlenmektedir. Örneğin yüz ilam içinde kamu yükseköğretim kurumları daire başkanlıklarının ön plana çıktığı diğer harcama birimlerinin geride kaldığı gözlemler arasında yerini almaktadır. Denetim açısından durum normal olmakla birlikte, kamu yükseköğretim kurumları açısından kurum içi mali hususların düzene sokulması açısından 
sorunlu görülebilir. Örneğin kamu yükseköğretim kurumları bilimsel araştırma projeleri koordinatörlüğü ilk akla gelen birim olarak göze çarpmaktadır. Bilimsel araştırma projeleri koordinatörlügü gelirleri yine üniversite döner sermayesi gayrisafi hasılatı ve tezsiz yüksek lisans programları gelirlerinden ayrılan paylar gibi öz gelirlerle finanse edilen bir birimdir. Dış denetim açısından incelenen dönem ve ilamlarda bilimsel araştırma proje biriminin hiç yer almamış olması dikkat çekicidir. Her ne kadar mal ve hizmet alımları açısından, 4734 sayılı Kamu İhale Kanunu 3. maddesi f) fikrası göre kanundan istisna edilmiş ise de gerek yönetmelikler gerekse Maliye Bakanlığı ve Bakanlar Kurulu Kararı düzenlemeleri ile 4734 sayılı Kanununa dolaylı olarak bağlanan birimin, denetiminin sınırlı olması bir eksiklik olarak değerlendirilebilir.

İkinci olarak inceleme konusu ilamlar bakımından, dış denetimin ya da kamu zararının konusu olarak ücret ve ücretin unsurlarına yoğunlaşmış olmasının da sınırlılıklar getirdiği düşünülmektedir. Kamu yükseköğretim kurumları; şartlı ve şartsız bağışların kullanımından, mal ve hizmet alımına kadar farklı birimlerde farklı mali işlemler gerçekleştirmektedirler. Bu alanlarda da kamu zararı ortaya çıkabileceği noktasından hareketle mali işlemlerin tümünü kapsayacak ve idareye yol gösterecek şekilde denetimlerin yaygınlaştırılması gerektiği ileri sürülebilir.

Üçüncü ve son olarak, kamu zararında sorumluluk olgusunun tartışmaya yer bırakmayacak şekilde açıklığa kavuştuğu ileri sürülebilir. Zira ilamlarda ne karar verilmiş olursa olsun tutarlı bir biçimde harcama yetkilileri ile ödeme belgesi ve eklerini düzenlemekle görevli olanların sorumlu olduğu istikrar kazanmıştır.

\section{Kaynaklar}

Bülbül, D. \& Y. Akpınar \& İ.H. Bekar (2015), Kamu Zararı (Yargı Kararları Işı̆̆ııda), Vizyon, Ankara.

European Commision (2006), Welcome to the World of PIFC: Public Internal Financial Control, Directorate General for Budget, European Commision, Brussels, <http://ec.europa.eu/budget/library/biblio/documents/control/brochure_pifc_en_pdf>, 21.07.2016.

Kılıçoğlu, A.M. (2001), Borçlar Hukuku, Turhan Kitabevi, Ankara.

Yereli, A.B. \& D. Bülbül (2013), "Mali Yönetim ve Mali Denetim Açısından Kamu Zararı”, VI.

Yerel Yönetimlerin Mali Yönetimi Forumu, 11-12 Aralık 2013, Ankara,

<www.tbb.gov.tr>, 11.07.2016.

Özçelik, B. (2012), “5018 Sayılı Kamu Mali Yönetimi ve Kontrol Kanunu’na Göre Kamu Zararında Sorumluluk", Panel Kamu Zararı 150. Y11, Ankara.

Sarıyar, S. (2008), Kusurun Tanımı ve Öznelliği, Hubyar Vakfi, İstanbul, <http://www.hubyar.eu/Default.asp?page=2\&ref=28>, 20.07.2016.

Tosun, M.U. (2014), Devlet Üniversitesi Bütçeleri (150 Soruda), Sonçağ Kitabevi, Ankara. 